研究論文

\title{
夏季における沿岸レクリエーション用水域の ふん便性細菌の調查
}

古川隼士**川畑勇人*·鈴木祥広*

\begin{abstract}
要 旨
本研究では, 宮崎市の沿岸レクリエーション用水域を中心に, ふん便污染の指標細菌であるふん便性
大腸菌群 $(\mathrm{FC})$ および腸球菌（ENT）の実態調查を行った, 調查期間は, 梅雨期間と海水浴場開放期 間を含む2009年 6 月〜 9 月とした。沿岸水中の FC および ENTの細菌数は, それぞれ BDL (Below detection limits, 検出下限值以下) $\sim 6.3 \times 10^{3} \mathrm{CFU} / 100 \mathrm{~mL}$ および $\mathrm{BDL} \sim 5.2 \times 10^{2} \mathrm{CFU} / 100 \mathrm{~mL}$ の範 囲で検出され，調查日および調査地点によって大きく変動した，調査期間において，いずれのふん便性 細菌についてもUSEPAの水質基準值を超えて検出される場合があった，また，両ふん便性細菌ともに 前日降水量と高い正の相関（FC： $r=0.83, E N T ： r=0.99 ）$ を示した，逆に，塩分とは負の相関を示 した (FC： $\mathrm{r}=-0.60, \mathrm{ENT}: \mathrm{r}=-0.75)$. PCR 法による腸球菌種の同定試験では, 各調查地点から 単離した腸球菌株のうち, 主に人畜のふん便に由来するとされる Enterococcus faecium と Enterococcus faecalis が高頻度で同定された地点もあった。降雨時には, 沿岸レクリエーション用水域の数地点は, 人畜を起源とするふん便污染を受けていることが示唆された。

キーワード：ふん便性細菌, 沿岸レクリエーション用水域, ふん便性大腸菌群, 腸球菌, PCR
\end{abstract}

\section{1.はじめに}

現在, 沿岸環境に打ける病原性微生物（病原性大腸 菌, クリプトスポリジウム, ジアルジア，㧍よびサル モネラ等) による污染が問題視されて㧍り ${ }^{1,2)}$, 先進 国とされる日本や欧米に扔いてさえも，ヒトへの感 染・発症リスクは無視できないといわれている年年. 沿岸環境における微生物学的な水質の悪化は, 水系感 染症等の公衆衛生上の問題だけでなく, レクリエー ション用水域，あるいは漁港・養殖場等の閉鎖に伴う 経済的な損失についても影響を及ぼす可能性もある. アメリカ合衆国では, 病原性微生物の存否, および潜 在的リスクの指標となるふん便指標細菌のガイドライ

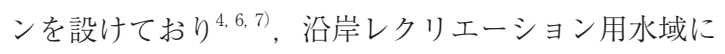
扮けるふん便性細菌の污染状況等に関する知見・情報
が蓄積されている ${ }^{8-12)}$.また, 実際に, 沿岸域における モニタリング調査によって,ふん便性細菌の基準值を 満たさなかった海水浴場は閉鎖勧告を受けている ${ }^{13)}$. その一方で, 我が国では, 海水浴場については開放期 間の前にヒトへの健康リスクを鑑みて，ふん便性大腸 菌群の調査が実施されているが, 公衆衛生を目的とし た細菌学的調査を継続的に実施した事例はそれほど多 くなく ${ }^{14,15)}$, 沿岸域に扔けるふん便指標細菌の污染状 況等に関する知見・情報はそしいのが現状である。し たがって, 真に安心・安全な沿岸環境を構築するため には，沿岸環境における衛生管理に関わるふん便性細 菌污染を調查し, 現状を正確に把握することが重要で ある。

これまでの著者らの研究において, 沿岸域における ふん便性大腸菌群抢よびふん便性連鎖球菌は, 一年間 
の中でも，梅雨期間から夏期に高濃度で検出され，特 に降雨後に濃度が高くなる傾向を示している ${ }^{15)}$ ，そこ で本研究では, 宮崎市内の沿岸レクリエーション用水 域（海水浴場，サーフィンエリア）を中心に，ふん便 指標細菌であるふん便性大腸菌群 ( $\mathrm{FC})$, および腸球 菌(ENT)のモニタリング調査を行った。調査期間は, 海水浴場の開放等によって沿岸域の利用人口が増加す ると考えられる 6 月〜9月とした。

ふん便污染はヒト由来あるいは非ヒト由来(動物等) に大別される．水環境におけるふん便污染によるヒト への健康リスクはヒト由来のふん便性微生物の方が寄 与率は高いといわれており, 重要視されている ${ }^{16)}$. そ こで, 腸球菌種の中でも特にヒトの腸管内に多く存在 し，ブタやウシ等の家畜動物からもたびたび検出され る Enterococcus faecium と Enterococcus faecalisにつ いて, 各調査地点から腸球菌株を単離・培養し, ポリ メラーゼ連鎖反応 (Polymerase Chain Reaction : PCR)法によって菌種の同定を行った。これによって, 沿岸域に扔ける人畜由来のふん便性細菌污染の存否に ついて評価した。

\section{2. 材料と方法}

\section{1 調 查 概 要}

調査は, 宮崎市沿岸域におけるレクリエーション用 水域(海水浴場, サーフィンエリア，抢よびヨットハー バー）を中心に，全11地点（地点 $\mathrm{A} \sim \mathrm{K} ）$ を対象とし て実施した（図 1 )。地点 $\mathrm{B}, I$, および $\mathrm{K}$ は夏季に 扔いて海水浴場として開放されている。地点 $\mathrm{A}$ ，およ び $\mathrm{E} 〜 \mathrm{G}$ は，サーフィンエリアとして年間を通じて利 用されている。特に, 地点 $\mathrm{G}$ は夏季にサーフィンの国 際大会も開催されている地点である。地点 $\mathrm{C}$ および $\mathrm{D}$ は，それぞれヨットハーバー㧍よび港であり，地点 J は宿泊施設前にあるビーチである，調査は，特に公衆 衛生上重要であると考えられる梅雨期間から海水浴場 開放期間を中心に，2009年の 6 月 4 日〜 9 月 9 日の期 間において, 計 9 回実施した。宮崎県の位置する九州 南部の梅雨期間は2009年 6 月 2 日〜 7 月 12 日（期間総 雨量, $283 \mathrm{~mm}$ ), 宮崎市内の海水浴場開放期間は 7 月 4 日〜8月31日であった.

\section{2 試料採取と測定項目}

沿岸水は波打ち際から約 $10 \mathrm{~m}$ 以内, 水深約 $50 \mathrm{~cm}$ 程度の表層水を採取し, ポリエチレン容器に保存した。 採取した試料は実験室に持ち帰り，直ちに FC 抄よび

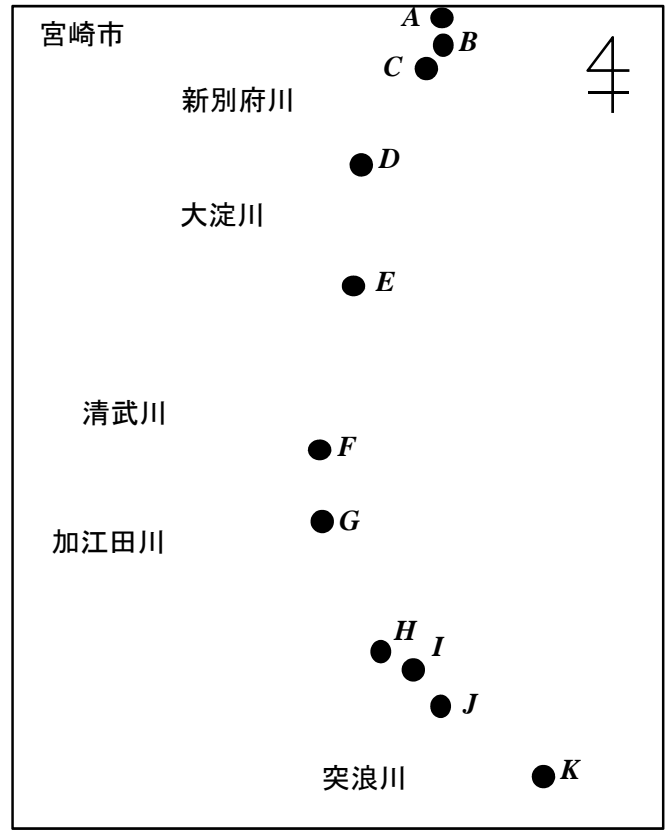

図 1 調査地点

ENT の測定に用いた。 また，一般水質項目として， 沿岸水の $\mathrm{pH}$ (東亜電波工業, ガラス電極式水素イオ ン濃度計, HM-30G), 電気伝導度 (EC, 東亜電波工業, 電気伝導度計, CM-30S), および濁度（カオリン， 三菱化学, 積分球式濁度計, SEP-PT-706D）を測定 した。沿岸水の塩分は $\mathrm{EC}$ から算出し ${ }^{17)}$, 水温は試料 採取時に棒状温度計を用いて測定した。降水量は気象 庁のホームページ上に公開されている日降水量デー夕 を用いた ${ }^{18)}$.な㧍, 調査エリア周辺には 2 ヶ所(宮崎, 青島）の降水量観測地点があるが，両者の降水量に有 意差がなく，エリア内には同等量の降雨があったと考 えられるため, 宮崎（観測地点）の降水量データのみ を用いた（表 1 )。

\section{表 1 調査日および前日降水量}

\begin{tabular}{rrc}
\hline 水質調查日 & $\begin{array}{c}\text { 降水量観測日 } \\
\text { (調查日前日) }\end{array}$ & $\begin{array}{c}\text { 降水量 } \\
\text { (mm/day) }\end{array}$ \\
\hline 2009.6 .4 & 2009.6 .3 & 15.5 \\
6.11 & 6.10 & 12 \\
6.24 & 6.23 & 129.5 \\
7.1 & 6.30 & 0.5 \\
7.8 & 7.7 & 0 \\
7.23 & 7.22 & 6 \\
8.2 & 8.1 & 0 \\
8.19 & 8.18 & 31 \\
9.9 & 9.8 & 0 \\
\hline
\end{tabular}




\section{3 細菌計数法}

FC および ENT の計数はメンブランフィルター法 に従った. $10 \mathrm{~mL}$ あいは100 $\mathrm{mL}$ の沿岸水試料をメ ンブランフィルター（孔径 $0.45 \mu \mathrm{m}$, Advantec) を 用いて濾過した。細菌の濃度が高いと思われる試料に ついては, 必要に応じて10～100倍希釈し，希釈した

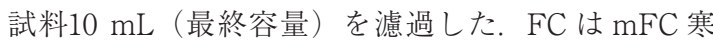
天培地（DIFCO）上にフィルターを置き, $44.5 \pm 0.2$ ${ }^{\circ} \mathrm{C}$ で24時間水浴培養後, フィルター上の青色のコロ ニーを計数した. ENTは membrane-Enterococcus Indoxyl- $\beta$-D-Glucoside 寒天培地 ( $\mathrm{mEI}$ 培地) にフィ ルターを置き, $41.0 \pm 0.5^{\circ} \mathrm{C}$ で 24 時間培養後, フィルター 上の青色のコロニーを計数した．各細菌数は，3 連の ものを平均し100 mLあたりに換算した．FCおよび ENT の検出下限值はいずれも $1.0 \mathrm{CFU} / 100 \mathrm{~mL}$ であ り, それ以下の細菌数はBDL (Below detection limits：検出下限值以下）として示した.

\subsection{PCR 法による腸球菌種の同定}

各調査日において, 腸球菌数が高く検出された地点 について, フィルター上に形成された腸球菌株を単離 し，PCR 法による腸球菌種の同定を行った.

$\mathrm{mEI}$ 培地上に形成されたシングルコロニーをTodd Hewitt 培地（TH 培地, 寒天1.5\%, DIFCO）に釣菌 し, $37 \pm 1.0^{\circ} \mathrm{C}$ で24時間培養した。培養後, $\mathrm{TH}$ 培地に 形成されたシングルコロニーから DNAを抽出した。 DNA 抽出は Insta Gene Matrix（Bio Rad）を用いて, 付属の使用説明書に従った。この抽出したDNAをテ ンプレートとして用いて, PCR 法によって腸球菌種を 同定した.E. faecium と E. faecalis の PCR 法による 同定は, 表 2 に示すプライマーをそれぞれ用いた ${ }^{19,20)}$. PCR反応液は, $2.0 \mu$ Lの $10 \times$ Ex Taq Buffer (TaKaRa), $1.6 \mu \mathrm{L}$ の dNTP Mixture (TaKaRa, 最終濃度 : そ れぞれ0.2 mM)，各2.0 $\mu \mathrm{L}$ のプライマー $(1.0 \mu \mathrm{M})$, $0.2 \mu \mathrm{L}$ の TaKaRa Ex Taq HS (TaKaRa, $1.0 \mathrm{U}$ ), および $8.0 \mu \mathrm{L}$ の抽出 DNA に4.2 $\mu \mathrm{L}$ の滅菌蒸留水を 加え, 全量 $20 \mu \mathrm{L}$ に調整した. PCR 反応はサーマル
サイクラー (iCycler, Bio Rad) を用いて, 以下に示 す条件で行った． $95^{\circ} \mathrm{C} て ゙ 4$ 分間の熱変性処理後, $95^{\circ} \mathrm{C}$ で30秒，アニーリングを $54^{\circ} \mathrm{C}$ (E. faecium) あるいは $62^{\circ} \mathrm{C}$ (E. faecalis) で 1 分間，および $72^{\circ} \mathrm{C} て ゙ 1$ 分間を

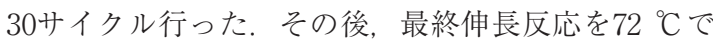
5 分間行った. PCR 反応後, $1.5 \%$ アガロースゲルで 電気泳動 (PowerPac Basic, Bio Rad)を行い, エチジ ウムブロマイドで染色して PCR 増幅産物を確認した。

\section{3. 結果と考察}

\section{1 一般水質項目}

表 3 に沿岸水試料の水温, $\mathrm{pH}$ ，濁度，および塩分 を示す，沿岸水の水温は，調査期間中において29.7 $23.2^{\circ} \mathrm{C}$ の間で変動した。 $\mathrm{pH}$ は，いずれの地点におい ても8.1付近で安定していた。塩分は, 地点 D, E, およびFを除いて, 平均で30 psu 以上であった。地 点 $\mathrm{D}$ は宮崎港湾奥部であり，採取日によっては塩分が $20 \mathrm{psu}$ 以下を示す場合もあった。これは, 地点 Dが 下水処理場の雨水吐き室の吐き口からの越流水が流入 してくる地点付近であり，採取日によって塩分の変動 が大きいことからも，吐き口からの越流水の影響を受 けている可能性が考えられる。濁度は, 調査地点およ び調査日において大きく変動した。平均值で比較する と, 地点 $\mathrm{B}$ において最大の6.17 44.35 度を示し, 地点 $\mathrm{A}$,

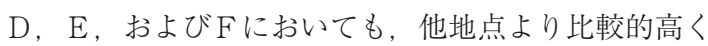

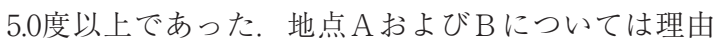
が不明であるが，地点 Dは雨水吐き室の吐き口からの

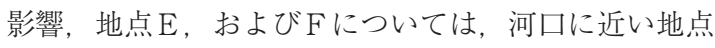
であるため（直線距離で500 $\mathrm{m}$ 以内），淡水流入の影 響を受けて濁度が高かったと考えられる。地点 $\mathrm{C} と \mathrm{~K}$ では，他の地点と比較して低い濁度であった。

\section{2 沿岸水中の FC および ENT の細菌数}

表 4 に各地点における沿岸水中の FC, および $\mathrm{ENT}$ の細菌数の測定結果を示す。沿岸水中の FCは, 全調 査地点において $\mathrm{BDL} \sim 6.3 \times 10^{3} \mathrm{CFU} / 100 \mathrm{~mL}$ の範囲 で検出された， $\mathrm{FC} の$ 細菌数の平均でみると, $\mathrm{FC}$ が

表2 プライマーの塩基配列（16S rRNA）

\begin{tabular}{|c|c|c|c|c|}
\hline 菌 種 & プライマー & 配列 (5’-3') & 増幅 DNA (bp) & 参考文献 \\
\hline E. faecium & $\begin{array}{l}\text { Efm-Forward } \\
\text { Efm-Reverse }\end{array}$ & $\begin{array}{l}\text { GAAAAAACAATAGAAGAATTAT } \\
\text { TGCTTTTTTGAATTCTTCTTTA }\end{array}$ & 215 & 19) \\
\hline E. faecalis & $\begin{array}{l}\text { Efs-Forward } \\
\text { Efs-Reverse }\end{array}$ & $\begin{array}{l}\text { GCCACTATTTCTCGGACAGC } \\
\text { GTCGTCCCTTTGGCAAATAA }\end{array}$ & 518 & 20) \\
\hline
\end{tabular}


表 3 各地点における一般水質項目

\begin{tabular}{|c|c|c|c|c|c|c|c|c|c|c|c|c|c|c|c|c|}
\hline \multirow[b]{2}{*}{ 地点 } & \multicolumn{4}{|c|}{ 水温 $\left({ }^{\circ} \mathrm{C}\right)$} & \multicolumn{4}{|c|}{$\mathrm{pH}$} & \multicolumn{4}{|c|}{ 濁度（度, カオリン） } & \multicolumn{4}{|c|}{ 塩分（psu） } \\
\hline & 最大 & 最小 & $\begin{array}{c}\text { 平均 } \\
\text { 値 }\end{array}$ & $\begin{array}{l}\text { 標準 } \\
\text { 偏差 }\end{array}$ & 最大 & 最小 & $\begin{array}{c}\text { 平均 } \\
\text { 值 }\end{array}$ & $\begin{array}{l}\text { 標準 } \\
\text { 偏差 }\end{array}$ & 最大 & 最小 & $\begin{array}{c}\text { 平均 } \\
\text { 值 }\end{array}$ & $\begin{array}{l}\text { 標準 } \\
\text { 偏差 }\end{array}$ & 最大 & 最小 & $\begin{array}{c}\text { 平均 } \\
\text { 值 }\end{array}$ & $\begin{array}{l}\text { 標準 } \\
\text { 偏差 }\end{array}$ \\
\hline A & 29.6 & 24.2 & 27.4 & 1.73 & 8.1 & 8.0 & 8.1 & 0.1 & 15.8 & 0.42 & 5.34 & 4.76 & 34.7 & 31.9 & 33.4 & 0.97 \\
\hline B & 29.7 & 25.6 & 27.5 & 1.46 & 8.1 & 7.9 & 8.1 & 0.1 & 11.8 & 0.31 & 6.17 & 4.35 & 34.8 & 31.5 & 33.4 & 1.07 \\
\hline $\mathrm{C}$ & 29.6 & 23.8 & 27.2 & 1.86 & 8.1 & 7.9 & 8.0 & 0.1 & 5.20 & 0.05 & 2.08 & 2.07 & 34.1 & 27.2 & 32.0 & 2.23 \\
\hline $\mathrm{D}$ & 29.4 & 23.7 & 27.1 & 1.85 & 8.2 & 7.8 & 8.0 & 0.1 & 15.6 & 1.50 & 5.08 & 4.67 & 34.5 & 13.4 & 25.3 & 7.15 \\
\hline $\mathrm{E}$ & 29.5 & 23.9 & 27.0 & 1.77 & 8.2 & 8.0 & 8.1 & 0.1 & 21.5 & 1.10 & 5.24 & 6.31 & 34.0 & 15.9 & 29.8 & 5.74 \\
\hline $\mathrm{F}$ & 29.2 & 23.7 & 26.9 & 1.66 & 8.2 & 8.1 & 8.1 & 0.0 & 21.7 & 0.40 & 5.27 & 6.49 & 34.3 & 15.9 & 29.4 & 5.57 \\
\hline G & 29.3 & 23.8 & 26.9 & 1.66 & 8.2 & 8.1 & 8.2 & 0.0 & 19.9 & 0.50 & 4.86 & 5.84 & 34.4 & 20.0 & 30.9 & 4.89 \\
\hline $\mathrm{H}$ & 29.4 & 23.8 & 27.1 & 1.64 & 8.3 & 8.0 & 8.2 & 0.1 & 16.1 & 0.60 & 4.81 & 4.82 & 34.5 & 22.5 & 31.2 & 4.00 \\
\hline I & 29.4 & 23.6 & 27.0 & 1.79 & 8.3 & 8.1 & 8.2 & 0.1 & 16.2 & 0.50 & 4.52 & 4.62 & 34.4 & 21.4 & 30.9 & 4.67 \\
\hline $\mathrm{J}$ & 29.0 & 23.2 & 26.8 & 1.80 & 8.2 & 8.1 & 8.2 & 0.1 & 8.26 & 0.40 & 4.17 & 2.96 & 34.8 & 22.0 & 32.0 & 3.92 \\
\hline $\mathrm{K}$ & 28.9 & 23.5 & 26.8 & 1.70 & 8.2 & 8.1 & 8.2 & 0.0 & 6.10 & 0.40 & 2.93 & 2.07 & 34.5 & 23.2 & 32.1 & 3.66 \\
\hline
\end{tabular}

表 4 各地点における沿岸水中のふん便性細菌数

\begin{tabular}{|c|c|c|c|c|c|c|c|c|}
\hline \multirow{2}{*}{ 調査地点 } & \multicolumn{4}{|c|}{$\mathrm{FC}(\mathrm{CFU} / 100 \mathrm{~mL})$} & \multicolumn{4}{|c|}{$\mathrm{ENT}(\mathrm{CFU} / 100 \mathrm{~mL})$} \\
\hline & 最大 & 最小 & 平均值 & 標準偏差 & 最大 & 最小 & 平均值 & 標準偏差 \\
\hline A & 11 & 0 & 5 & 4.5 & 7 & 0 & 2 & 2.5 \\
\hline B & 63 & 0 & 10 & 21 & 3 & 0 & 1 & 1.1 \\
\hline $\mathrm{C}$ & 10 & 1 & 3 & 3.3 & 10 & 0 & 2 & 3.2 \\
\hline $\mathrm{D}$ & $6.3 \times 10^{3}$ & 0 & $1.5 \times 10^{3}$ & $2.3 \times 10^{3}$ & 230 & 0 & 65 & 78 \\
\hline $\mathrm{E}$ & $3.1 \times 10^{3}$ & 1 & $3.6 \times 10^{2}$ & $1.0 \times 10^{3}$ & $5.2 \times 10^{2}$ & 0 & 60 & $1.7 \times 10^{2}$ \\
\hline $\mathrm{F}$ & $6.5 \times 10^{2}$ & 0 & 97 & $2.1 \times 10^{2}$ & $3.2 \times 10^{2}$ & 0 & 39 & $1.1 \times 10^{2}$ \\
\hline G & $9.8 \times 10^{2}$ & 1 & $1.6 \times 10^{2}$ & $3.3 \times 10^{2}$ & $1.3 \times 10^{2}$ & 0 & 27 & 51 \\
\hline $\mathrm{H}$ & $2.0 \times 10^{2}$ & 0 & 37 & 73 & $1.2 \times 10^{2}$ & 0 & 14 & 39 \\
\hline I & $2.4 \times 10^{2}$ & 0 & 29 & 79 & $1.2 \times 10^{2}$ & 0 & 13 & 38 \\
\hline $\mathrm{J}$ & $1.3 \times 10^{2}$ & 0 & 39 & 54 & 41 & 0 & 8 & 13 \\
\hline K & 75 & 0 & 13 & 25 & 30 & 0 & 5 & 9.7 \\
\hline
\end{tabular}

最も高濃度で検出されていた地点は, 地点 $\mathrm{D}$ （宮崎港 湾奥部)であり $\left(1.5 \times 10^{3} \mathrm{CFU} / 100 \mathrm{~mL}\right)$, この地点は, 調査期間を通じて FC が高い細菌数で検出された. 次 いで,サーフィンエリアとして利用されている地点 $\mathrm{E}$, $\mathrm{F}$, およびGにおいて高い細菌数で検出され, 平均值 はそれぞれ3.6×10² CFU/100 mL, 97 CFU/100 mL, および $1.6 \times 10^{2} \mathrm{CFU} / 100 \mathrm{~mL}$ であった。沿岸水中の ENTは, 全調査地点において BDL $5.2 \times 10^{2}$ $\mathrm{CFU} / 100 \mathrm{~mL}$ の範囲で検出された. ENTの細菌数の 平均で見てみると $\mathrm{FC} よ り 1 〜 2$ オーダー低い值で 検出される傾向を示した，また，地点別にみると FC と同様に地点Dでは調査期間を通じて他の地点よりも 高い細菌数で検出され, 平均值においても最も高い細 菌数であった $(65 \mathrm{CFU} / 100 \mathrm{~mL})$. また, 地点 $\mathrm{E}, \mathrm{F}$,

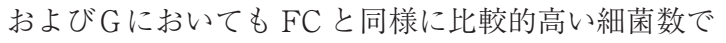
検出される傾向であった。 これらの 3 地点はいずれも 河口に近い地点である。地点 $\mathrm{E}$ は, 宮崎県内の中心市 街地（宮崎市，都城市等）を流下する大淀川（一級河
川, 流域面積 : $2,230.0 \mathrm{~km}^{2}$, 流路延長 : $107.0 \mathrm{~km}$ ）河

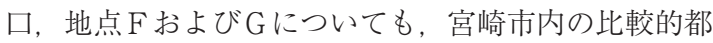
市化された地域を流下する清武川（二級河川，流域面 積 : $179.9 \mathrm{~km}^{2}$, 流路延長 : $45.9 \mathrm{~km}$ ）河口に, それぞ れ位置しており, 河口から離れている他地点よりは, 陸域からの淡水流入の影響を受けやすいと推測され, ふん便性細菌が高い值で検出される傾向にあったと考 えられる。

調査期間中, いずれのふん便性細菌も調査地点・調 査日によって，細菌数は大きく変動した，調査期間を 通じて，FC および ENTが高い細菌数で検出された 地点 D (宮崎港湾奥部) は, 下水処理場の雨水吐き室 の吐き口が隣接しており，そこからの越流水の影響に よって，たびたび細菌数が高くなることがあり，両ふ ん便性細菌の平均細菌数が高くなったと推察される.

\section{3 各調查地点における細菌数の変化}

全調査地点のうち, 公衆衛生上重要であると考えら れる地点, 海水浴場として開放される地点（地点 $\mathrm{B}$, 
I，およびK)，サーフィンエリアとして頻繁に利用 されている地点 (地点 $\mathrm{A}, \mathrm{E}, \mathrm{F}, \mathrm{G}$, およびH), および各ふん便性細菌が高濃度で検出された地点 Dに ついて, 各調査日における細菌数の変化を検討した。 図２に各地点における沿岸水中の FCおよび ENT の 細菌数の変化を示す。海水浴場およびサーフィンエリ アについてみると, いずれのふん便性細菌についても 6 月下旬と 8 月中旬の調査日において, 高い細菌数で 検出された。 6 月24日における FC およびENT の細

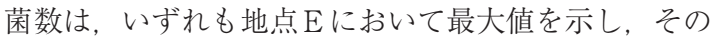
細菌数は，それぞれ3.1×10 $\mathrm{CFU} / 100 \mathrm{~mL}$ および5.2 ×10² CFU/100 mLであった。また，8月19日では， 地点 $\mathrm{G}$ において高い細菌数を示し, その $\mathrm{FC}$ おび ENT の細菌数は，それぞれ $9.8 \times 10^{2} \mathrm{CFU} / 100 \mathrm{~mL}$ お よび $1.1 \times 10^{2} \mathrm{CFU} / 100 \mathrm{~mL}$ であった。高濃度のふん便
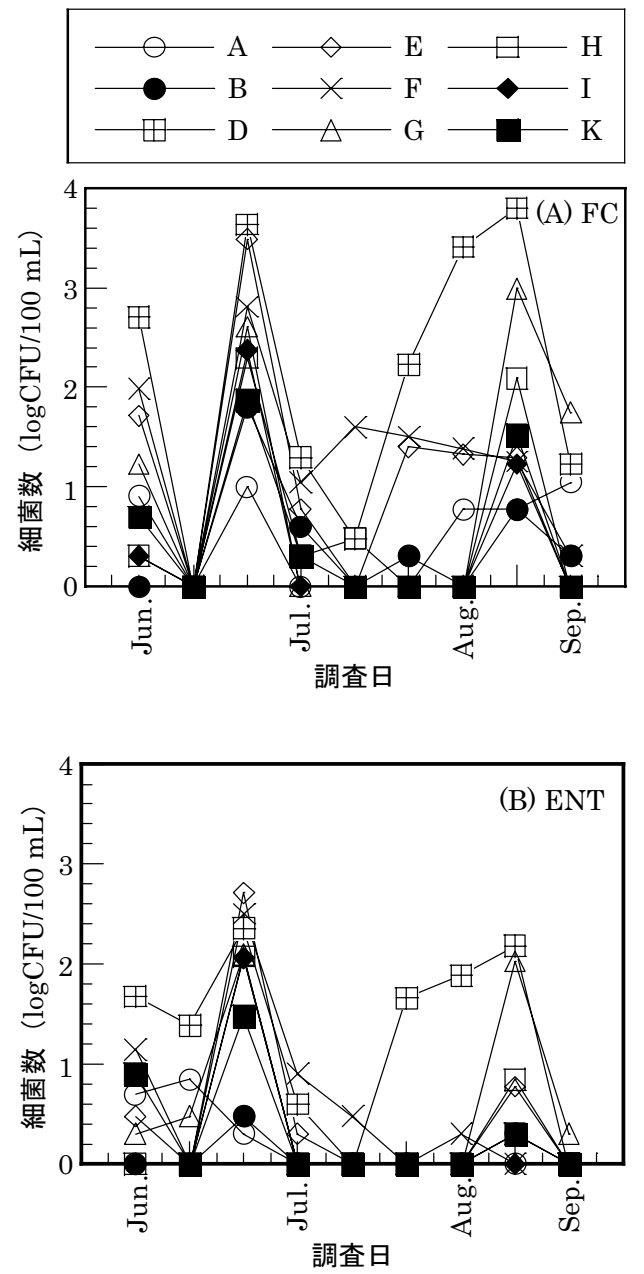

図 2 FC および ENT の細菌数の変化
性細菌が検出された 6 月24日および 8 月19日の前日の 降水量は, それぞれ $129.5 \mathrm{~mm} /$ day および31.0 mm/ dayであった.したがって, 降雨の影響によって，陸域 から高濃度のふん便性細菌が沿岸域に流入したものと 考えられる. 細菌数の平均值が最も高かった地点 Dは, $\mathrm{FC}$ および ENTともに他地点よりも高濃度で検出さ れる傾向を示した. 他地点と同様に, 降雨後において細 菌数が高くなる一方で, 降水量がそれほど高くなかっ た調査日についても FC と ENT が高濃度で検出され る場合があった。地点 $\mathrm{D} は$ は港として利用されており， 他の調査地点よりは比較的閉鎖的である. そのため, 降 雨初期におけるフラッシュアウトによって雨水吐き室 から流入したふん便性細菌が, 地点 $\mathrm{D}$ 付近に蓄積し, 降 雨が記録されなかった調査日においても，FCと ENT が検出された可能性が考えられる。この地点はレクリ エーション用水域としては利用されていないが，この 地点において高濃度で存在したふん便性細菌が周辺の 沿岸域に拡散していく可能性も否定できない.

U. S. Environmental Protection Agency (USEPA) が制定している海域のレクリエーション用水域におけ る $\mathrm{FC}$ と $\mathrm{ENT}$ の水質基準は，それぞれ800 CFU/100 $\mathrm{mL}^{6)}$ と $104 \mathrm{CFU} / 100 \mathrm{~mL}^{4)}$ となっている. FCにつ

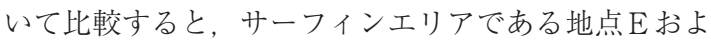
びGにおいて,それぞれ 1 回ずつ基準值を超過したが, 海水浴場である 3 地点はすべての調査日において基準 值以下であった。一方で, ENTについてはサーフィ ンエリアである地点 $\mathrm{E}, \mathrm{F}, \mathrm{G}$, およびHにおいて, 少なくとも 1 回以上は基準值以上で検出された. また, 海水浴場である地点 I においても 6 月の調査日におい て, 基準值以上の $116 \mathrm{CFU} / 100 \mathrm{~mL}$ で検出されたが, これは海水浴場の開放期間外であった。

我が国における海水浴場等における水浴場水質判定 基準は， FCについて設けられている ${ }^{21)}$. その判定基 準は, FCの細菌数を用いて「適（不検出～100個 $/ 100 \mathrm{~mL}$ 以下) 」, 「可（400個 /100 mL 以下〜1,000個 $/ 100 \mathrm{~mL}$ 以下)」, および「不適（1,000個 /100 mL を 超えるもの)」に区分される。本調査期間における $\mathrm{FC}$ の細菌数は，いずれの調査日においても「適」, あるいは「可」に区分される結果となった。

\section{4 各項目と細菌数との関係}

$\mathrm{FC}$ と ENT の細菌数と, 各項目 (水温, $\mathrm{pH}$, 濁度, 塩分，および前日降水量）との関連性について検討し た（表 5 )。 FC と ENT との間には有意な正の相関関 
表 5 各乃ん便性細菌と各項目との関係

\begin{tabular}{cccccccc}
\hline & $\begin{array}{c}\mathrm{FC} \\
(\mathrm{CFU} / 100 \mathrm{~mL})\end{array}$ & $\begin{array}{c}\mathrm{ENT} \\
(\mathrm{CFU} / 100 \mathrm{~mL})\end{array}$ & $\mathrm{pH}$ & $\begin{array}{c}\text { 水温 } \\
\left({ }^{\circ} \mathrm{C}\right)\end{array}$ & $\begin{array}{c}\text { 塩分 } \\
(\mathrm{psu})\end{array}$ & $\begin{array}{c}\text { 濁度 } \\
(\text { 度 })\end{array}$ & $\begin{array}{c}\text { 降水量 } \\
(\mathrm{mm} / \text { day })\end{array}$ \\
\hline $\mathrm{FC}$ & 1 & & & & & & \\
$\mathrm{ENT}$ & $0.65^{*}$ & 1 & & & & \\
$\mathrm{pH}$ & $-0.30^{*}$ & -0.22 & 1 & & & \\
水温 & 0.09 & -0.03 & -0.20 & 1 & & \\
塩分 & $-0.60^{*}$ & $-0.75^{*}$ & $0.27^{*}$ & -0.03 & 1 & \\
濁度 & $0.29^{*}$ & $0.69^{*}$ & -0.17 & -0.01 & $-0.48^{*}$ & 1 & \\
降水量 & $0.83^{*}$ & $0.99^{*}$ & - & - & - & - & 1 \\
\hline
\end{tabular}

$* \mathrm{p}<0.01$

係が認められた（ $\mathrm{r}=0.65 ）$. 各ふん便性細菌と塩分 との間には有意な負の相関関係を示した $(\mathrm{FC} ： \mathrm{r}=$ -0.60$, ENT : $r=-0.75)$. これまでの研究において, FC およびENT は塩分と中位以上の負の相関を示す ことが報告されており ${ }^{22,23)}$ ，本研究においても同様の 傾向を示した。また，いずれのふん便性細菌も前日降 水量と極めて高い正の相関関係を示し， FC および ENTで，それぞれ $\mathrm{r}=0.83$ 拉よび $\mathrm{r}=0.99$ であった。 アメリカにおけるモニタリング調査では，降雨後に沿 岸域に打いてふん便性細菌数が著しく高くなることが 指摘されて抢り ${ }^{24,25)}$ ，海水浴場に扔いては，ふん便性 細菌がUSEPA の基準值を上回って検出されることが 報告されている ${ }^{26)}$ 。また，降雨によって都市排水や都 市河川水等の陸域からの沿岸域への流出量が増加する ことが, 沿岸域の細菌学的な水質悪化に強く関連して いることも示されている ${ }^{26)}$. したがって，宮崎市の沿 岸レクリエーション用水域においても降雨による影響 を受け，ふん便性細菌の濃度が上昇することが示唆さ れた。

以上のことから，沿岸環境におけるふん便性細菌は 降雨等の天候による影響を受けて濃度が増減すること が推察される。また，都市化が進んだ地域を流下する 河川の河口付近，および下水処理場の雨水吐き室のよ うな点源污染が隣接する地点においても，ふん便性細 菌が高濃度で検出される傾向を示した。したがって, 今後はふん便性細菌の測定に加えて, 有機物污染指標 となる $\mathrm{COD}$ や栄養塩類（窒素リン等）についても 分析し、より詳細にふん便污染の挙動に関する検討を 行う必要がある。

\section{5 腸球菌種の同定}

ふん便性細菌污染の実態調査において, 各調査日の 腸球菌が高い菌数で検出された地点から腸球菌株を単 離・培養し，PCR 法によって腸球菌種を同定した。
対象としたE. faecium と E. faecalis は, 腸球菌種の 中でも特にヒトの腸管内に多く存在しており, ブタや ウシ等の家畜動物からも検出される菌種である. 特に, ヒトの胃腸管内に限定すれば，全腸球菌種に対する割 合は, E. faecium と E. faecalis の 2 菌種で 9 割以上

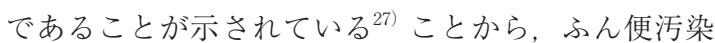
指標として重要視されている菌種である。すなわち, これら 2 菌種の沿岸域に扮ける存在割合を知ること で，人畜に由来するふん便污染について明らかにする ことが可能である。

表 6 に各調査地点から単離した腸球菌株の同定結果 を示す。なお，今回は腸球菌が高濃度で検出された地 点D，F， G， I，J，およびKからそれぞれ80株， 20株，40株，20株，20株，および40株を単離して同定 試験を行ったＥ．ｆaecium は，調査したすべての地

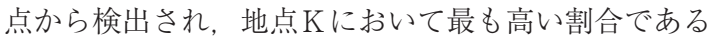
60\%を示した．E. faecalis は地点D，G，およびIに おいて検出された，地点 $\mathrm{D}$ を除いて E. faecium の方 がE. faecalis よりも高頻度で検出された。 E. faecium と E. faecalis を合計した存在割合でみてみると，地 点Jに扔いて最も低い10\%程度であった，それに対し て, 地点 $\mathrm{D}, \mathrm{I}$ ，およびKにおいては，40\%以上の存 在割合であった。したがって，地点 $\mathrm{D}, \mathrm{I}$ ，および $\mathrm{K}$ は人畜由来のふん便性細菌による污染を強く受けてい

表 6 PCR 法による腸球菌種の同定

\begin{tabular}{cccc}
\hline \multirow{2}{*}{ 地点 } & $\begin{array}{c}\text { 単離 } \\
\text { 株 }\end{array}$ & \multicolumn{2}{c}{ 菌株数 } \\
\hline $\mathrm{D}$ & E. faecium & E. faecalis \\
\hline $\mathrm{D}$ & 80 & $14(18 \%)^{*}$ & $21(26)$ \\
$\mathrm{F}$ & 20 & $3(15)$ & $0(0)$ \\
$\mathrm{G}$ & 40 & $4(10)$ & $2(5)$ \\
$\mathrm{I}$ & 20 & $7(35)$ & $1(5)$ \\
$\mathrm{J}$ & 20 & $2(10)$ & $0(0)$ \\
$\mathrm{K}$ & 40 & $24(60)$ & $0(0)$ \\
\hline *括弧内は存在割合 &
\end{tabular}


ることが示唆された.

宮崎市沿岸域を対象としたふん便性細菌の実態調 査, さらに遺伝子学的手法による人畜由来のふん便性 細菌の存否の把握によって, 沿岸域に扔けるふん便性 細菌の污染状況に関する情報を得ることができた。ま た，沿岸水の塩分濃度の変化によって，陸域由来の淡 水が流入していることも推察できる，さらに， PCR 法による腸球菌種の同定によって, 人畜由来のふん便 性細菌の存在を明らかにすることができた。しかしな がら，沿岸域における細菌学的な水質モニタリングの みでは，ふん便性微生物の污染源を特定することは極 めて困難である。したがって, 沿岸域に扔けるふん便污 染の根本的な解決を図るためには, 細菌学的水質調査 に加え, 遺伝子学的手法や生化学的手法を用いた污染 源追跡手法が極めて重要なツールとなる.ふんん便性微 生物污染の追跡手法開発に関する研究は, 著者らの研 究を含め ${ }^{28,29)}$, 世界中で積極的に推進されている ${ }^{1,2,16)}$. 沿岸域に扔ける公衆衛生の改善に寄与するためにも, ふん便性細菌による污染状況に関する知見・情報の集 積に加え, 污染源追跡に関する研究の今後のさらなる 推進が必要である.

\section{4. まとめ}

本研究では, 宮崎市の沿岸レクリエーション用水域 を中心に,ふん便性細菌である FC および ENT のモ二 タリング調查を実施した. 得られた知見を以下に示す。 (1) FC およびENTの細菌数は，それぞれ BDL 6.3 $\times 10^{3} \mathrm{CFU} / 100 \mathrm{~mL}$ 抢よび $\mathrm{BDL} \sim 5.2 \times 10^{2} \mathrm{CFU} / 100$ $\mathrm{mL}$ の範囲で検出され, 調査日拉よび調查地点によっ て大きく変動した。

(2)海水浴場あるいはサーフィンエリアとして頻繁に利 用されている地点における, 各ふん便性細菌の細菌数 の変化を検討したところ，海水浴場開放期間において は，FC および ENT の細菌数が USEPA の基準值を 超えることはなかった。 しかしながら，サーフィンエ リアではいずれの細菌数もたびたび基準值を超過して 検出される場合があった。

(3)各ふん便性細菌と前日降水量に極めて高い正の相関 関係があった $(\mathrm{FC}: \mathrm{r}=0.83, \mathrm{ENT}: \mathrm{r}=0.99)$ ，逆に，

各ふん便性細菌と塩分濃度との間にも有意な負の相関 関係が認められた $(\mathrm{FC}: \mathrm{r}=-0.60, \mathrm{ENT}: \mathrm{r}=-0.75)$. したがって，沿岸域のふん便性細菌は天候等の影響を 受けて，変動することが考えられる。また，河口，お
よび点源污染付近の地点は, 両ふん便性細菌が高濃度 で検出される傾向を示した。

(4) PCR 法によるE. faecium と E. faecalis の同定結果 から,これら 2 種類の腸球菌種が 40 ～60\%の高い割合で 存在する地点があり,これらの地点は人畜を起源とし たふん便性細菌の影響を受けていることがわかった。

\section{参考文献}

1 ) Scott, T. M., Rose, J. B., Jenkins, T. M., Farrah, S. R., and Lukasik, J.; Microbial source tracking: current methodology and future directions, Appl. Environ. Microbiol., 68, (12), 5796-5803, 2002.

2 ) Meays, C. L., Broersma, K., Nordin, R., and Mazumder, A.; Source tracking fecal bacteria in water: a critical review of current methods, J. Environ. Manage., 73,(1), 71-79, 2004.

3 ) Cabelli, V. J., Dufour, A. P., McCabe, L. J. and Levin, M. A.; Swimming-associated gastroenteritis and water quality, Am. J. Epidemiol., 115, (4), 606-616, 1982.

4 ) U. S. Environmental Protection Agency.; Ambient water quality criteria for bacteria -1986, EPA A440/5-84-002. Office of Water, Washington, DC., 1986.

5 ) Alexander, L. M., Heaven, A., Tennant, A. and Morris, R.; Symptomatology of children in contact with sea water contaminated with sewage, J. Epidemiol. Community Health, 46, (4), 340-344, 1992.

6 ) U. S. Environmental Protection Agency.; Quality criteria for water. EPA-440976023. Office of Water, Washington, DC., 1976.

7 ) U. S. Environmental Protection Agency.; Bacterial water quality standards for recreational waters (freshwater and marine waters), EPA-823-R-03-008, Washington DC., 2003.

8 ) Haack, S. K., Fogarty, L. R. and Wright, C.; Escherichia coli and enterococci at beaches in the Grand Traverse Bay Lake Michigan: sources, characteristics, and environmental pathways, Environ. Sci. Technol., 37,(15), 275-3282, 2003

9 ) Delille, D. and Gleozon, F.; Distribution of enteric bacteria in Antarctic seawater surrounding the Portaux-Français permanent station (Kerguelen Island), Mar. Pollut. Bull., 46, (9), 1179-1183, 2003.

10) Noble, R. T., Leecaster, M. K., McGee, D. C., Weiberg, S. B. and Ritter, K.; Comparison of bacterial indicator analysis methods in stormwater-affected coastal waters, Water Res., 38, (5), 1183-1188, 2004.

11) Shibata, T., Solo-Gabriele, H. M., Fleming, L. E. and Elmir, S.; Monitoring marine recreational water quality using multiple microbial indicators in an urban tropical environment, Water Res., 38, (13), 3119-3131, 2004.

12) Chigbu, P., Gordon, S. and Strange, T.; Influence of interannual variation in climatic factors on fecal coliform level in Mississippi Sound, Water Res., 38, (20), 43414352, 2004.

13) Morrison, C. R., Bachoon, D. S. and Gates, K.W.; Quantification of enterococci and bifidobacteria in Georgia estuaries using conventional and molecular methods, Water Res., 42, (14), 4001-4009, 2008. 
14）山本攻; 大阪市に拈けるし尿海洋投棄処分と大阪市立衛 生研究所が果した役割，生活衛生，51，（3），178-184， 2007.

15）古川隼士，川畑勇人，鈴木祥広；沿岸レクリエーション エリアにおけるふん便性細菌污染の調查, 環境技術, 39, (8), 493-499, 2010.

16) Field, K. G., and Samadpour, M.; Fecal source tracking, the indicator paradifm, and managing water quality, Water Res., 41, (16), 3517-3538, 2007.

17）松山優治；3-6 塩分, 地球環境調査計測辞典 第 3 巻 沿岸 域編, 竹内均 編, 221-222, 1986, フジ・テクノシステム, 東京, 2003 .

18）国土交通省気象庁；気象統計情報, 気象庁,(オンライン), $<$ http://www.jma.go.jp/jma/menu/report.html>, （参照 2011-06-10).

19) Jackson, C. R., Fedorka-Cray P. J., and Barrett, J. B.; Use of a genus- and species-specific multiplex PCR for identification of enterococci, J. Clin. Microbiol., 42, (8), 3558-3565, 2004.

20) Liu, D., Wang C., Swiatlo E. J., and Lawrence, M. L.; PCR amplification of species-specific putative transcriptional regulator gene reveals the identify of Enterococcus faecalis, Res. Microbiol., 156, (9), 944-984, 2005.

21）環境省水 - 大気環境局 ; 水浴場水質調査結果, 環境省,(才 ンライン), <http://www.env.go.jp/water/suiyoku_cho/ index.html>, (参照2011-06-10).

22) Lipp, E. K., Farrah, S. A. and Rose, J. B.; Assessment and impact of microbial fecal pollution and human enteric pathogens in a coastal community, Mar. Pollut. Bull., 42, (4), 286-293, 2001.
23) Troussellier, M., Got, P., Bouvy, M., M’Boup, M., Arfi, R., Lebihan, F., Monfort, P., Corbin, D. and Bernard, C.; Water quality and health status of the Senegal River estuary, Mar. Pollut. Bull., 48, (9-10), 852-862, 2004.

24) Reeves, R. L., Grant, S. B., Mrse, R. D., Copil Oancea, C. M., Sanders, B. F., and Boehm, A. B.; Scaling and management of fecal indicator bacteria in runoff from a coastal urban watershed in southern California, Environ. Sci. Technol., 38, (9), 2637-2648, 2004.

25) Ahn, J. H., Grant, S. B., Surbeck, C. Q., DiGiacomo, P. M., Nezlin, N. P., and Jiang, S.; Coastal water quality impact of stormwater runoff from an urban watershed in southern California, Environ. Sci. Technol., 39, (16), 5940-5953, 2005.

26) Dorfman, M.; Testing the Waters: a Guide to Water Quality at Vacation Beaches, National Resource Defense Council, 2006.

27）国府島泉；水質污染指標としての腸球菌の菌種分類，日 本水処理生物学会誌，27，(1)，107-110, 1991.

28) Furukawa, T., Takahashi, H., Yoshida, T., and Suzuki, Y.; Genotypic analysis of enterococci isolated from fecalpolluted water from different sources by pulsed-field gel electrophoresis (PFGE) for application to microbial source tracking, Microbes Environ., 26, (2), 181-183, 2011.

29) Furukawa, T., Yoshida, T., and Suzuki, Y.; Application of PFGE to source tracking of fecal pollution in coastal recreation area: A case study in Aoshima Beach, Japan, J. Appl. Microbiol., 110, (3), 688-696, 2011.

\title{
Monitoring of Fecal Bacteria in a Coastal Recreation Area during Summer Months
}

\author{
Takashi FURUKAWA* , Hayato KAWABATA*, Yoshihiro SUZUKI* \\ * Department of Civil and Environmental Engineering, Faculty of Engineering, University of Miyazaki
}

\begin{abstract}
Fecal coliform $(\mathrm{FC})$ and enterococci(ENT), frequently used as fecal indicators were monitored in the coastal recreation area of Miyazaki, Japan, from June to September 2009. The FC and ENT counts in coastal water were found to range from Below detection limits(BDL) to $6.3 \times 10^{3} \mathrm{CFU} / 100 \mathrm{~mL}$ and from BDL to $5.2 \times 10^{2}$ CFU/100 mL, respectively. These counts varied depending on the numbers of sampling days and stations, and exceeded the criteria for marine recreation water recommended by the US Environmental Protection Agency during sampling events. Both bacteria showed a significant positive correlation with rainfall ( $F C$ : $r=0.83$, ENT: $r=0.99)$, and a negative correlation with salinity (FC: $r=-0.60$, ENT: $r=-0.75)$. In the identification test of enterococcal strains using PCR, Enterococcus faecium and Enterococcus faecalis were detected at high frequencies in some stations. Our findings demonstrate that during heavy rains, some stations in the coastal recreation area could be affected by fecal pollution from human and livestock feces with the inflow of inland water.
\end{abstract}

Key Words : Fecal bacteria, Coastal recreation areas, Fecal coliform, Enterococci, PCR 